\title{
Kesetaraan Gender Dalam Keluarga Untuk Peningkatkan Taraf Hidup Masyarakat Dusun Sempu, Wonokerto, Kabupaten Sleman
}

\author{
Dian Azmawati1, Wahyuni Kartikasari² \\ 1,2 Program Studi Ilmu Hubungan Internasional, Fakultas IImu Sosial dan IImu Politik, Universitas Muhammadiyah Yogyakarta \\ Jl. Brawijaya, Tamantirto Kasihan, Bantul, DIY 55183 Telp. 0274-387656 ext. 118 \\ Email: dianazmawati@umy.ac.id \\ DOI: 10.18196/ppm.34.303
}

\begin{abstract}
Abstrak
Dusun Sempu berada di kaki gunung Merapi, Sleman, Daerah Istimewa Yogyakarta. Sebagai salah satu dari 13 dukuh di Desa wonokerto, Kecamatan Turi, Kabupaten Sleman, Provinsi Daerah istimewa Yogyakart, mayoritas warga dusun bermata pencaharian sebagai petani, khususnya salak. Sempu memiliki 330 kk, dengan jumlah penduduk 1136, terdiri dari laki-laki 574 jiwa dan jumlah perempuan sebanyak 562 jiwa. Dusun ini sudah cukup maju, tampak dari kondisi ekonomi sebagian besar warganya dan fasilitas pendidikan serta kesehatan yang baik.

Dalam aspek sosial kemasyarakatan, warga dusun sudah cukup maju dengan aktifnya organisasi, seperti organisasi kepemudaan yaitu Kelompok Karang Taruna dan arisan, serta keagamaan seperti TPA. Kegiatan musyawarah sering dilakukan oleh masyarakat Dukuh Sempu dalam rangka mencari sebuah solusi, dalam pertemuan arisan antar RT, rapat ibu-ibu PKK, Pertemuan bapak-bapak atau pada perkumpulan yang diadakan di Dukuh Sempu. Namun pengambilan keputusan masih sering dilakukan hanya dengan mendengarkan keputusan dari kaum laki-laki, sehingga peran perempuan dalam musyawarah dan pengambilan keputusan masih rendah. Kultur sosial budaya yang ada menempatkan perempuan pada kelas kedua. Hegemoni budaya patriarkhi menempatkan laki-laki sebagai pemimpin dalam keluarga, organisasi, maupun politik, sehingga partisipasi perempuan dalam pengambilan keputusan masih relatif rendah, sehingga perempuan lebih memilih bersikap pasif. Kondisi tersebut mendorong kami untuk meningkatkan keterlibatan perempuan dalam pemberdayaan masyarakat agar pembangunan dusun Sempu dapat berjalan dengan lebih baik. Melalui kegiatan pengabdian dengan tema "Kesetaraan Gender", diharapkan dengan keterlibatan perempuan, pembangunan yang berjalan menjadi sensitif terhadap kebutuhan berbagai elemen dalam masyarakat, salah satunya adalah perempuan.
\end{abstract}

Kata Kunci: Gender, kesetaraan, pemberdayaan, pembangunan

\section{Pendahuluan}

Konsep gender sering menimbulkan kerancuan makna. Di satu sisi, gender bermakna perbedaan fundamental secara biologis antara laki-laki dan perempuan. Secara lebih jauh lagi, perbedaan tersebut melahirkan ketidaksetaraan yang dikonstruksi secara sosial dalam hal peran dan kekuasaan atau hirarki dalam masyarakat. Di Indonesia, sebagian besar masayaraktanya menganut budaya patriarki, di mana laki-laki mendominasi sebagian besar kehidupan dalam keluarga dan masyarakat, dan demikian pula yang terlihat di dalam masyarakat dusun Sempu, Wonokerto. Meski sudah terdapat sejumlah organisasi dan perkkumpulan yang mellibatkan wanita, pengambilan keputusan penting lebih banyak masih didominasi oleh laki-laki. Pentingnya kesetaraan gender dalam pembangunan, sangat disadari oleh masyarakat internasional, dan dituangkan dalam berbagai program di dalam Sustainable Development Goals (SDGs). Indonesia merupakan salah satu negara yang secara aktif mengimplementasikan SDGs ke dalam perencanaan pembangunan. SDGs ke 5, yaitu Mencapai kesetaraan gender dan memberdayakan semua perempuan dan anak perempuan, memiliki tujuan sebagai berikut:

1. Mengakhiri segala bentuk diskriminasi terhadap semua perempuan dan anak perempuan dimana saja

2. Mengeliminasi segala bentuk kekerasan terhadap perempuan dan anak perempuan pada ruang publik dan privat, termasuk perdagangan (trafficking) dan seksual dan bentuk eksploitasi lainnya

3. Menghapukan segalasemua praktek-praktek yang membahayakan, seperti perkawinan anak, dini dan paksa dan sunat pada perempuan 
4. Menyadari dan menghargai pelayanandan kerja domestik yang tidak dibayar melalui penyediaan pelayanan publik, kebijakan perlindungan infrastruktur dan sosial serta mendorong adanya tanggung jawab bersama didalam rumah tangga dan keluarga yang pantas secara nasional

5. Memastikan bahwa semua perempuan dapat berpartisipasi penuh dan mendapat kesempatan yang sama untuk kepemimpinan pada semua level pengambilan keputusan dalam kehidupan politik, ekonomi dan publik

6. Memastikan adanya akses universal terhadap kesehatan seksual dan reproduksi dan hak reproduksi sebagaimana telah disepakati dalam Program Aksi Konferensi Internasional mengenai Kependudukan dan Pembangunan dan Aksi Platform Beijing dan dokumen hasil dari konferensi review keduanya

- Melakukan reformasi untuk memberikan hak yang sama bagi perempuan terhadap sumber-sumber ekonomi dan juga akses terhadap kepemilikan dan kontrol terhadap tanah dan bentuk property lainnya pelayanan finansial, warisan dan sumber daya alam, sesuai dengan hukum nasional

- Memperbanyak penggunaan teknologi terapan, khususnya teknologi informasi dan komunikasi, untuk mendukung pemberdayaan perempuan

- Mengadopsi dan menguatkan kebijakan yang jelas dan penegakkan perundang-undangan untuk mendorong kesetaraan gender dan pemberdayaan semua perempuan dan anak perempuan pada semua level (https://www.sdg2030indonesia.org/page/13-tujuan-lima).

Program pemerintah dalam pemberdayaan perempuan dan kesetaraan gender tersebut, masih sangat asing bagi warga dusun Sempu, Wonokerto. Sosialisasi mengenai program-program pemerintah dan pendampingan bagi warga masyarakat, khususnya perempuan di dusun Sempu diharapkan akan meningkatkan kesadaran meraka akan tanggung jawab dan hak mereka sebagai perempuan dalam berpartisipasi di dalam pembangunan bangsa, dan menghindarkan meraka dari tindakan-tindakan yang merugikan bahkan kekerasan terhadap perempuan.

\section{Metode Pelaksanaan}

Dalam tahap perencanaan dilakukan kegiatan-kegiatan sebagai berikut:

- Menetapkan tujuan program

- Menyusun prioritas kegiatan

- Menyusun jadwal

- Menyusun anggaran

\section{Tahap Pengorganisasian (organizing)}

Dalam tahap pengorganisasian dilakukan pembagian tugas dan tanggung jawab masing- masing orang yang terlibat.

\section{Tahap Pengarahan (actuating/leading)}

Dalam tahap ini tim pengusul PKM bekerja sama dengan kelompok wanita dusun Sempu melakukan usaha-usaha memotivasi semua pihak yang terlibat dan mengarahkan pekerjaan yang dilakukan. 


\section{Tahap Pengendalian (controlling)}

Dalam tahap ini, dilakukan evaluasi atas setiap kegiatan sedini mungkin untuk mengantisipasi masalah atau kegagalan.

\section{Hasil dan Pembahasan}

Masyarakat dusun Sempu sudah cukup maju dan aktifitas perempuan di dusun tersebut sudah cukup aktif dalam masyarakat. Namun pembuatan keputusan dalam berbagai kegiatan kemasyarakatan masih sangat didominasi oleh kaum lelaki. Tim pengabdian menawarkan solusi atas permasalahan kesetaraan gender yang dihadapi oleh masyarakat dusun Sempu, khususnya para wanita yang tergabung dalam PKK dusun Sempu, dengan melibatkan pula para bapak di dusun tersebut. Memberi sosialisasi berupa ceramah bagi masyarakat dan pendampingan pada PKK melalui diskusi serta simulasi tentang gender merupakan tujuan dari kegiatan tim pengabdian. Peningkatan kesadaran tentang kesetaraan gender diperlukan untuk kemajuan dan peningkatan taraf hidup masyarakat di dusun Sempu.

Sosialisasi kesetaraan gender bagi masyarakat dusun Sempu, Wonokerto, Sleman dilakukan melalui 2 kegiatan:

1.Sosialisasi berupa ceramah dengan melibatkan nara sumber dari beberapa bidang yang berbeda.

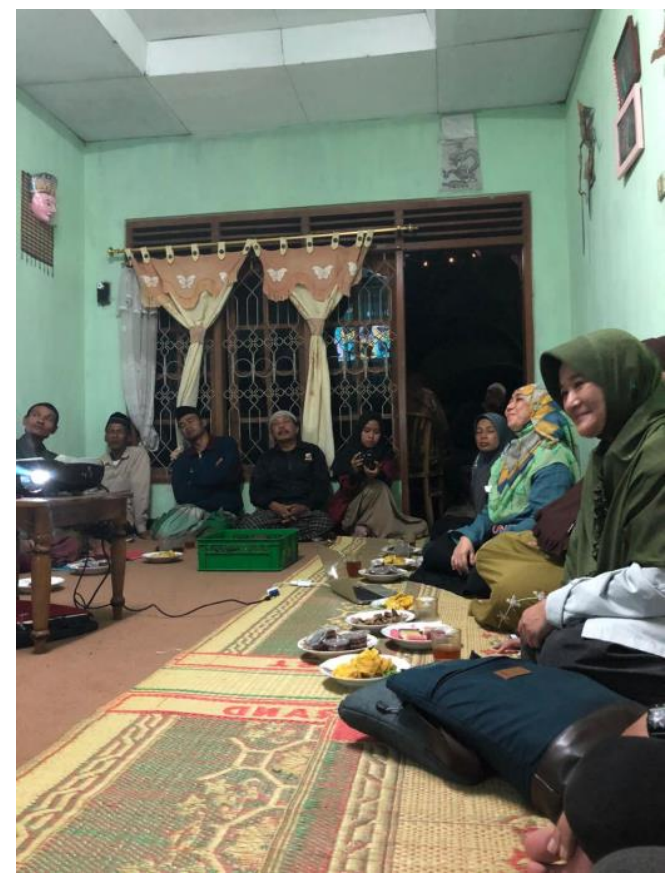

Pendampingan dalam diskusi-diskusi PKK tentang kesetaraan Gender. 


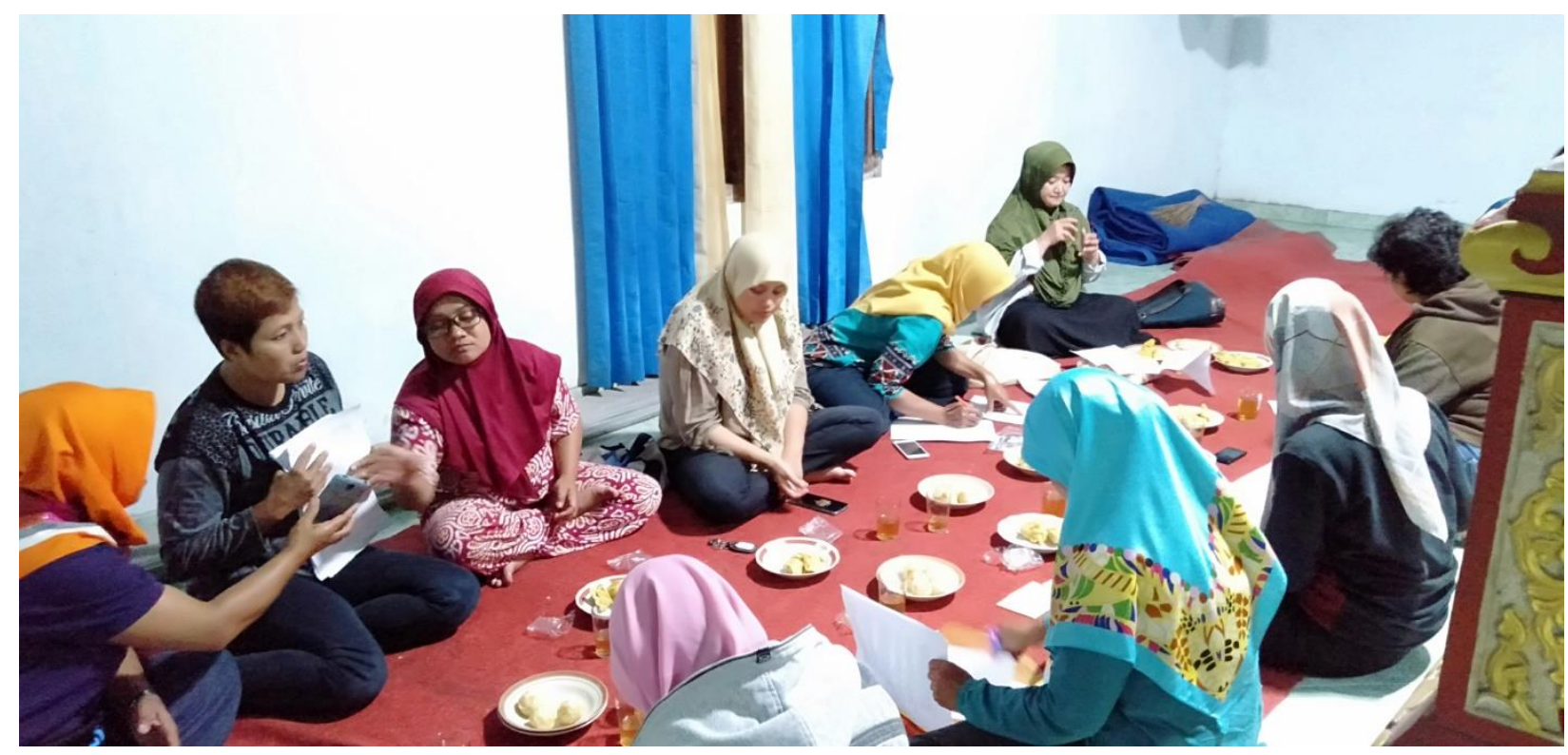

Pendampingan dalam persiapan lomba tentang Kesetaraan Gender yang diadakan oleh pemerintah daerah bagi ibu-ibu dan perempuan muda di dusun Sempu.

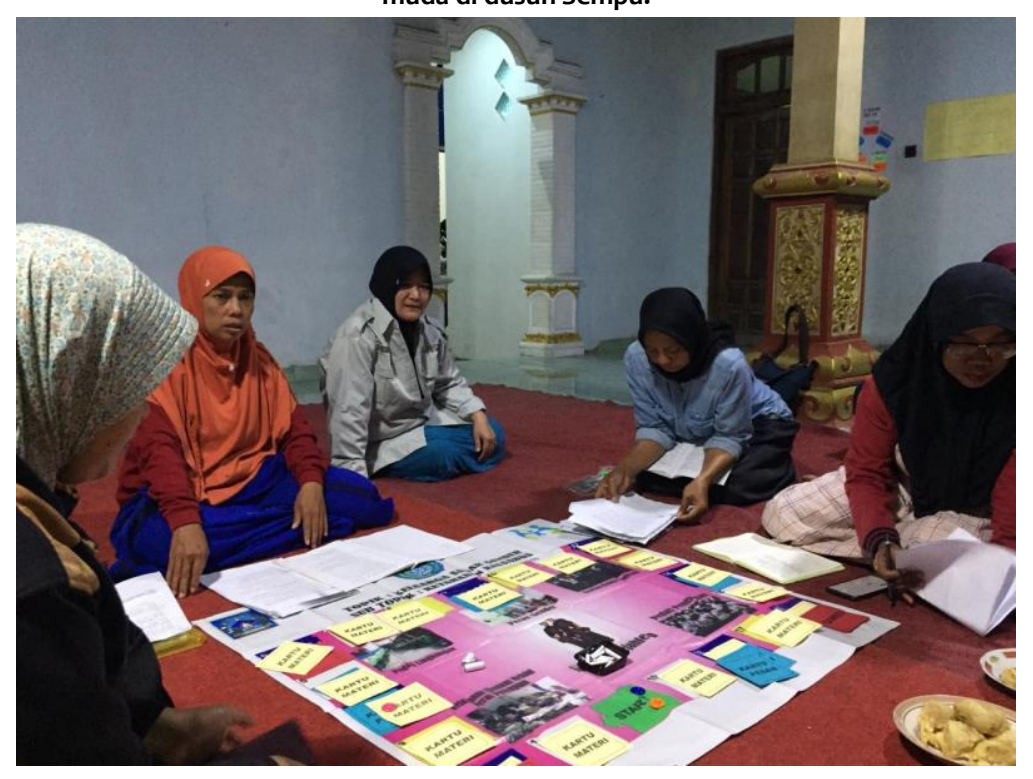

\section{Simpulan}

Kesetaraan gender di dusun Sempu masih mennjadi permasalahn dalam masyarakat dengan budaya paatriarkhi yang cukup kuat. Meskipun para wanita sudah turut berperan dalam kegiatan kemasyarakatan dan perekonomian keluarga, namun pembuatan keputusan penting masih didominsai oleh kaum lelaki. Tim pengabdian memberi sosialisasi tentang bagaimana kesetaraan gender dapat dibangun, dengan pendekatan nilai-nilai luhur yang sudah ada di dalam masyarakat. Pendampingan bagi persiapan lomba juga dilakukan, melalui simulasi dan diskusi tentang peran yang dapat diambbil oleh wanita, tanpa melanngagar kodrat sesuai nilai yang dipegang masyarakat. Setelah beberapa sesi sosialisasi dan diskusi ynag juga melibatkan kaum lelaki, dan pembahasan mengenai patriarkhi, kesadaran akan pentingnya dukungan laki-laki dalam membangun kesetaraan gender juga muncul di klangan kaum lelaki dusun Sempu. 


\section{Ucapan Terima Kasih}

Ucapan terima kasih kami sampaikan kepada:

1. Universitas Muhammadiyah Yogyakarta, dalam hal ini adalah Lembaga Penelitian, Publikasi dan Pengabdian Masyarakat (LP3M) sebagai pemberi dana dengan (SK Kepala LP3M Nomor: 031/PEN-LP3M/I/2020)

2. Kadus DusunSempu, Wonokerto, Sleman, DIYyang telah memberikan kepercayaan dan kesempatan keapda tim untuk melakukan kegiatan pengabdian.

3. Ketua PKK Dusun Sempu beserta pengurus dan anggotanya yang telah berkenan sebagai mitra pengabdian.

4. Ibu Nur Rahmi Budianti, Psi, yang telah berkenan memberi penyuluhan dan pendampingan bagi guru TK ABA dalam sosialisasi tentang peran ayah dalam keluarga.

5. Para donatur yang telah memberikan sumbangan berarti dalam program ini.

\section{Daftar Pustaka}

1. Salmon, Trevor C and Imber, Mark F, Issues in International Relations, Routledge, New York, 2008

2. (https://www.sdg2030indonesia.org/page/13-tujuan-lima).

3. https://www.id.undp.org/content/indonesia/en/home/sustainable-development-goals.html

4. https://www.unicef.org/indonesia/reports/roadmap-sdgs-indonesia

Acuan yang ada dalam daftar pustaka harus ada di dalam tubuh tulisan. Diupayakan acuanacuan rujukan terbaru, khususnya yang berbasis jurnal dan atau sitasi artikel ilmiah yang telah ditulis penulis sendiri di jurnal yang terbit sebelumnya. Daftar Pustaka dituliskan dengan menggunakan Mendeley style dan tersusun secara alfabetis dari A sampai Z. 